Sheffield Hallam

University
Centre for

Regional Economic and Social Research
Supported by

$J \boldsymbol{R F} F$

\title{
The Real Level of Unemployment 2017
}

Christina Beatty

Steve Fothergill

Tony Gore

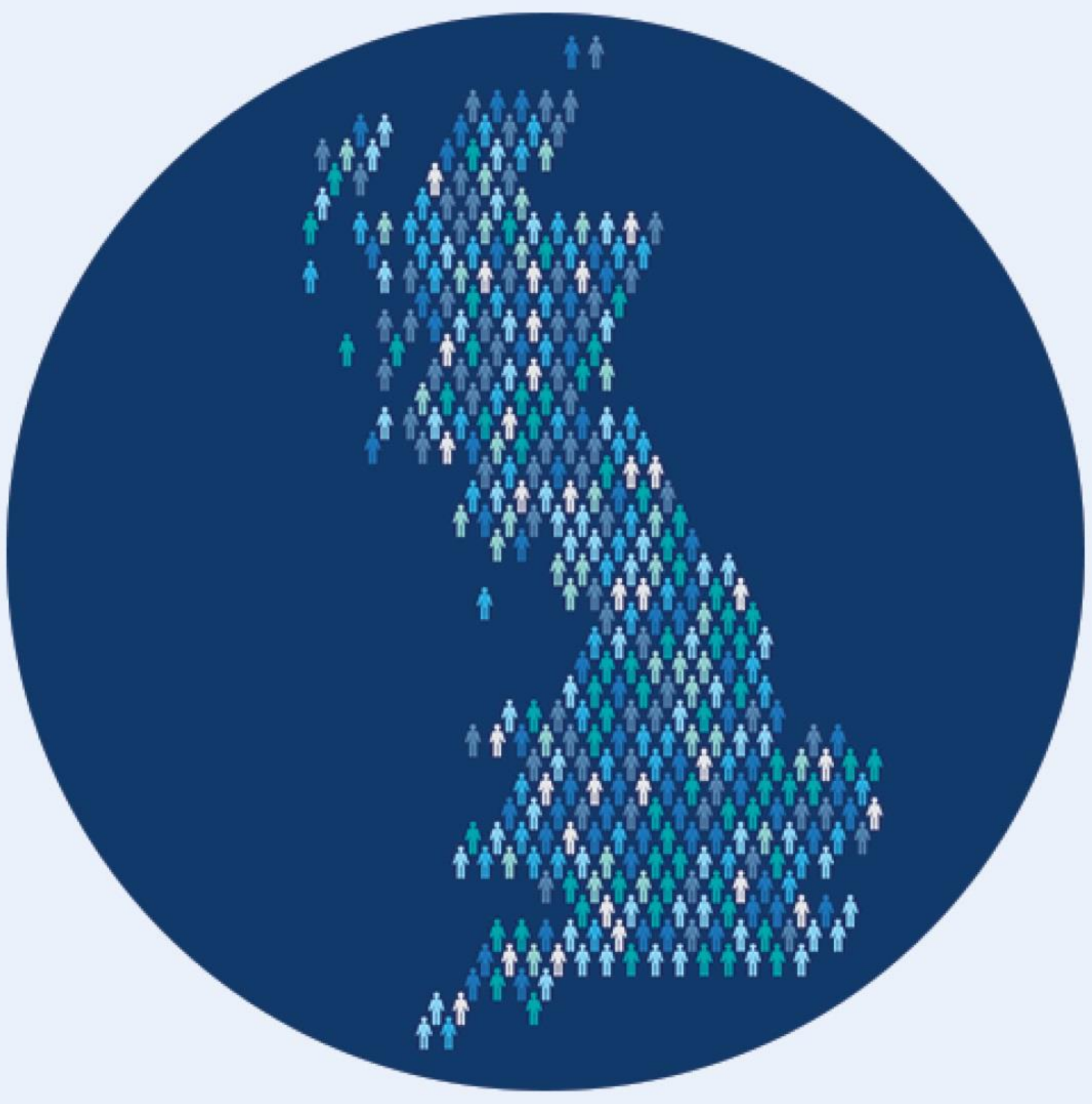





\section{THE REAL LEVEL OF UNEMPLOYMENT 2017}

Christina Beatty, Steve Fothergill and Tony Gore

Centre for Regional Economic and Social Research

Sheffield Hallam University

October 2017 


\section{Acknowledgement}

The revised method used in the report to estimate hidden unemployment has been developed with financial support from the Joseph Rowntree Foundation. The report's contents, however, remain the sole responsibility of the authors. 


\section{Key points}

- This report challenges the view that the UK economy is operating at or close to full employment. It presents alternative estimates of the level of unemployment, based on a re-working of official statistics, for every local authority district in England, Scotland and Wales.

- The report estimates that in 2017 the 'real level of unemployment' across Britain as a whole is nearly 2.3 million. This compares with just under 800,000 on the claimant count and 1.5 million on the wider ILO measure of unemployment preferred by the government.

- The report estimates that there are some 760,000 'hidden unemployed' on incapacity-related benefits (these days primarily Employment and Support Allowance). These are men and women who might have been expected to be in work in a genuinely fully employed economy. They do not represent fraudulent claims.

- The real level of unemployment and the scale of hidden unemployment have both fallen since 2012. However, there remain almost as many unemployed 'hidden' on incapacity benefits as 'visible' on the unemployment claimant count.

- Hidden unemployment is disproportionately concentrated in the weakest local economies, particularly Britain's older industrial areas and a number of seaside towns. The effect is to mask the true scale of labour market disparities between the best and worst parts of the country.

- In a number of local economies, including much of North East England, East Lancashire, Merseyside, the Welsh Valleys and the Birmingham and Glasgow areas, the real level of unemployment remains at or just below 10 per cent of the working age population. Much of southern and eastern England outside London, with real unemployment in the 2-3 per cent range, could however lay claim to operating near full employment. 


\section{The myth of full employment}

There is a view, popular with some commentators, that the UK economy is operating at or close to full employment. What is undeniable is that since 2012, when the recovery from recession began to get underway, employment has increased and unemployment has fallen. What is also true is that official statistics show that unemployment is now lower than an an time over the last thirty years. But that does not mean that the UK is near to full employment.

Actually, even the official statistics tell us that the economy isn't there yet. At around 1.5 million, the government's preferred measure of unemployment ${ }^{1}$ may be down on previous levels but hardly shows that problem has gone away. More significantly, in this report we show that substantial unemployment remains hidden, excluded from the official statistics. We also show that the hidden unemployment is disproportionately concentrated in the less prosperous parts of the country so that the differences across regions and local areas are far greater than those exposed by official statistics. In the less prosperous parts of Britain - in particular its older industrial areas and many seaside towns - full employment is still a long way off.

This is the fifth in a series of reports on the real level of unemployment that we have published at intervals since $1997^{2}$. The new report, like its predecessors, provides estimates for every local authority district in Great Britain. Here, we deploy essentially the same methods as in the earlier studies but with a number of important refinements. The central question remains the same: what is the real level of unemployment?

\section{Two official measures of unemployment}

The official measure of unemployment with the longest history is the claimant count - the number out-of-work claiming unemployment benefit, until recently Jobseeker's Allowance but increasingly Universal Credit on the grounds of unemployment. For many years the 'claimant count' and 'unemployment' were usually regarded as synonymous but this began to break down in the 1980 s and 90 s as changes to benefit rules started to reduce access to unemployment benefits. Increasing numbers of the unemployed therefore fell outside the

\footnotetext{
${ }^{1}$ ILO unemployment; see definition below.

${ }^{2}$ The previous reports were for 1997, 2002, 2007 and 2012.
} 
scope of the claimant count. These days, it is widely accepted that the claimant count covers only a proportion of the unemployed.

Nonetheless, the claimant count has a number of strengths. It is available monthly, it is very up-to-date (the figures are only four weeks old when they are released) and it provides information for small areas such as local authorities and wards. It is also a complete count, not a sample survey, so the figures are reliably accurate.

The other official measure is what is known as ILO unemployment. This is the number of people who meet the International Labour Organisation (ILO) criteria of unemployment, which is that they are out-of-work, available to start work in the next two weeks, and have looked for work in the last four weeks. This measure of unemployment is in theory independent of benefit status - you don't have to be claiming unemployment benefits to be included. The ILO criteria include many of the unemployed who are ineligible to receive benefit in their own right, for example because means-testing, and others who don't bother to sign on, perhaps to avoid a hassle that can result in only a modest financial return. Since 1997, the ILO measure has been the UK's officially preferred measure of unemployment and it is the one quoted most in the press.

A significant drawback of the ILO measure of unemployment is that it is based on a sample survey, the Labour Force Survey (also known in the UK as the Annual Population Survey). Like any sample survey, the estimates for areas where the sample is small, such as local authority districts, are therefore subject to a margin of error. For many years this meant that a great deal of district-level ILO unemployment data was simply too unreliable. However, more recently the Office for National Statistics has modified the raw district-level data to take account of the claimant count and sample sizes whilst still ensuring consistency with regional and national totals. The resulting district-level ILO unemployment estimates are more plausible than previously, though not without a residual margin of error owing to sampling.

Whereas in the 1980s and early 1990s the claimant and ILO measures of unemployment were not far apart in the UK, the gap has subsequently grown and, particularly over the last ten years, the number of ILO unemployed has far exceeded the number of claimant unemployed.

\section{Hidden unemployment: the role of incapacity benefits}

To understand how substantial unemployment remains hidden from either of the official measures it is useful to begin by looking at long-term trends in the numbers claiming the three main out-of-work benefits, shown in Figure 1 for 1979 to 2017 for Britain as a whole.

The numbers claiming unemployment benefits reached 3 million in the mid-1980s, fell back, rose again in the early 1990s, then declined to well under a million. In the wake of the 2008 financial crisis the numbers peaked at around 1.5 million before falling back once more. The numbers claiming lone parent benefits - Income Support for most of this period - rose from around 300,000 at the start of the 1980s to a peak of around 1 million in the mid-1990s. More recently, the numbers on lone parent benefits have fallen, not least because eligibility has gradually been restricted just to those with the very youngest children. 


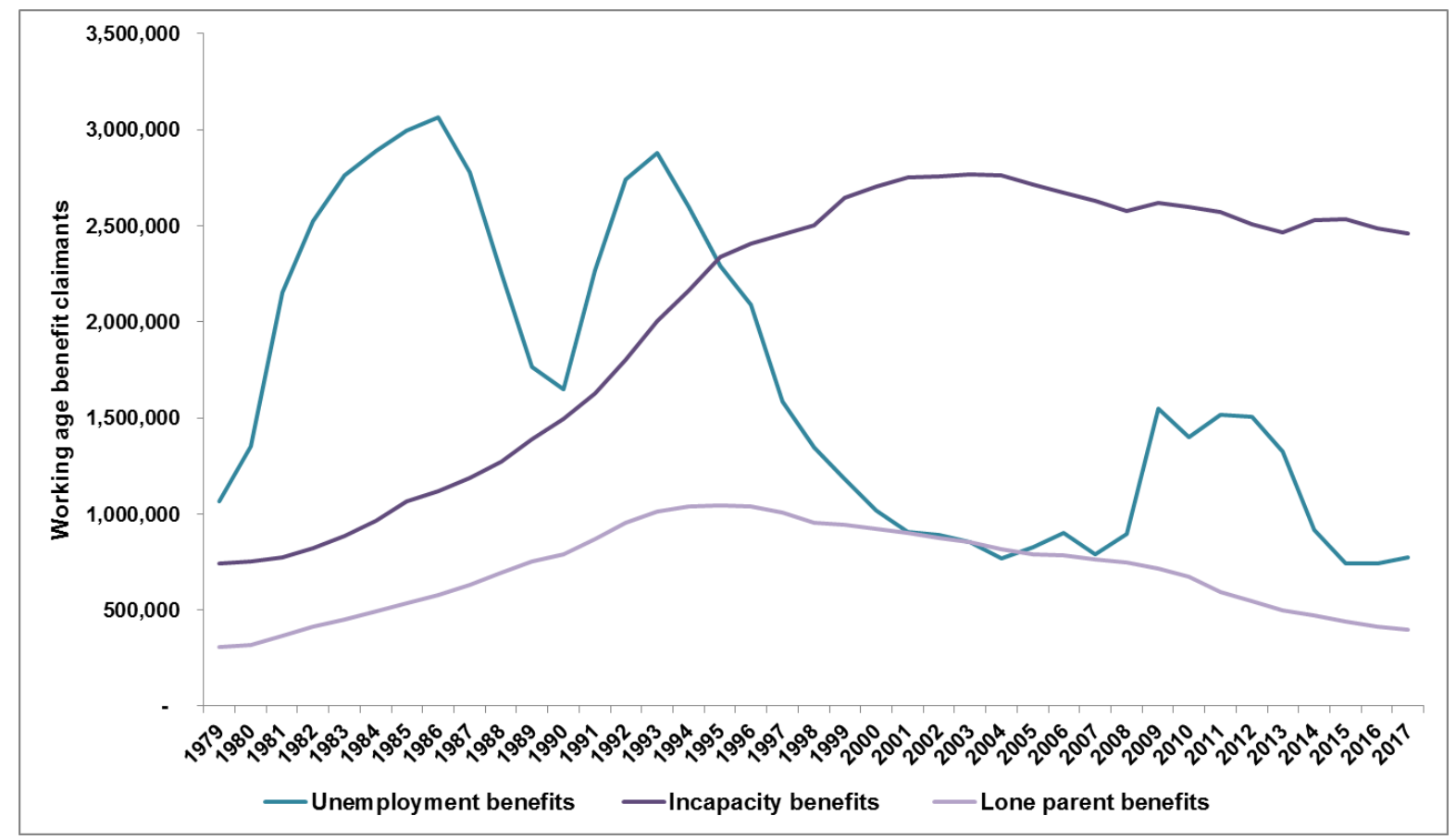

Source: DWP

The striking feature in Figure 1, however, is the rise in the numbers out-of-work on incapacity-related benefits, these days Employment and Support Allowance (ESA) but previously Incapacity Benefit (Invalidity Benefit before 1995), Income Support on grounds of disability and Severe Disablement Allowance. The number on these benefits rose from around 750,000 to a plateau of around 2.5 million. The numbers have declined a little from the all-time high in the early 2000 s but not by much.

There are two remarkable aspects of the incapacity numbers. First, they are largely invisible. The figures surface in the media from time to time but probably few beyond those who follow these issues would be aware that the numbers currently out-of-work on incapacity-related benefits exceed the numbers on unemployment benefits by more than three-to-one and that, the immediate post-financial crisis years excepted, this has been the situation since the end of the 1990s. The other remarkable aspect of the incapacity numbers is that they have stayed so high for so long despite multiple efforts to bring them down. Clearly, the factors that underpin incapacity claimant numbers are very powerful indeed. Moreover, it is impossible to explain the increase in health terms alone, especially at a time when general standards of health have slowly been improving, albeit with the smallest improvements among the most disadvantaged groups.

The relevance to the measurement of unemployment is that the jobless who suffer from health problems or disabilities generally claim incapacity benefits instead of unemployment benefits. They are therefore omitted from the claimant count and, if they fail to meet the criteria, they are omitted from the ILO unemployment figures as well.

Beyond a short 'Assessment Phase', access to Employment and Support Allowance is determined by a medical test, the Work Capability Assessment, carried out by contractors 
working for the Department for Work and Pensions. Some claimants are deemed 'fit for work' at this point and denied ESA. Those whose entitlement to ESA is confirmed are then placed in either the 'Support Group', intended for those with the most severe health problems or disabilities, or in the 'Work-Related Activity Group'. In the latter, claimants are required to prepare to return to work as their health or disability improves and, since 2012 , their entitlement to ESA has in all cases been means-tested after 12 months.

In practice, many unemployed people have picked up injuries over the course of their working life and there is the effect on physical capabilities of illness, disease and simply getting older. On top of this, mental health problems such as stress and depression are widespread. In practice, therefore, many of the unemployed with health problems or disabilities do qualify ESA rather than unemployment benefits. In many circumstances their benefit entitlement is a little higher than on unemployment benefits, and there is no requirement to sign on every fortnight.

ESA claimants then nearly all drop out of the ILO measure of unemployment because they do not look for work. Incapacity benefits, including ESA, have never made job-seeking a condition of entitlement. In practice, most claimants take a dim view of their job prospects because they feel their health isn't good enough or their disability too severe, or because they come to the conclusion that they would be unlikely to find work, especially when there is competition from fit and healthy workers who can often be viewed more favourably by employers because they haven't had period out of work due to ill health or disability. Furthermore, there can be a fear among incapacity claimants that to look for work would actually bring their benefit status into question.

The net result is that the very large numbers claiming ESA hide unemployment. This does not imply, of course, that the health problems or disabilities are anything less than real, or that the benefit claims are in any way fraudulent. The important point is that ill health or disability is not necessarily always an insuperable obstacle to employment. Indeed, the government's own Labour Force Survey estimates that of the 6.1 million adults of working age who have a work-limiting disability, 2.7 million are in employment - an employment rate of 44 per cent $^{3}$. So where jobs are readily available, many men and women with health problems or disabilities do hold down employment. But where jobs are in short supply, the men and women with health problems or disabilities are one of the prime groups that struggles to maintain a foothold in a competitive labour market.

This is transparent from regional data. In the North East of England in 2016-17, the employment rate among men and women with a work-limiting disability was just 37 per cent. In Scotland it was 38 per cent, in Wales 39 per cent and in North West England 40 per cent. By contrast, it was 53 per cent in South East England, 52 per cent in the South West, and 50 in Eastern England ${ }^{4}$. This strongly correlates with the strength of local labour markets.

The distribution of incapacity claimants around the country underlines this point. There are exceptional concentrations in places such as South Wales, Merseyside, North East England and Clydeside, where incapacity claimants can account for up to 10 per cent of the entire

\footnotetext{
${ }^{3}$ GB figures for April 2016 to March 2017.

${ }^{4}$ Source: Labour Force Survey, April 2016 to March 2017.
} 
working age population. These are places where standards of health have long been known to be below the national average but a generation or more ago the incapacity claimant rates in these places were far lower. What these places have in common is that they have all experienced large-scale industrial job losses, creating an imbalance in local labour markets that has persisted through to the present day. Conversely, in nearly all the south and east outside London, where the economy is stronger, the incapacity claimant rate remains just 3 or 4 per cent. This pattern is exactly what could be expected as a result of the diversion of men and women onto incapacity benefits in areas where jobs are harder to find.

\section{Measuring 'real unemployment'}

The 'real level of unemployment', as defined in this report, is the sum of three elements:

- The claimant count unemployed

- The additional ILO unemployed

- The hidden unemployed among incapacity claimants

The first element - the claimant count - is straightforward. The figures used here are for May 2017.

The second element - the additional ILO unemployed - is measured here as the difference between the claimant count and ILO unemployment ${ }^{5}$. In our previous reports we took the view that the district-level ILO unemployment data was unreliable and therefore made a flatrate adjustment based on the more robust regional data. However, the district-level ILO unemployment estimates do now appear to have improved. Here, we therefore use the official data, by local authority district, for the year April 2016 to March 2017.

The third element - the hidden unemployed among incapacity claimants - is unavoidably more difficult to measure. The previous reports in this series used a sophisticated benchmarking approach to measure this element of unemployment. For each district, a 'benchmark' incapacity claimant rate was generated based on the claimant rate in fully employed parts of southern England and on underlying differences in the extent of incapacitating ill health or disability between each district and this fully-employed part of southern England. For each district, this benchmark was intended to reflect what should be achievable if the local economy was operating at full employment. Excesses over the benchmark were deemed to be a form of hidden unemployment.

The fundamentals of this benchmarking approach are tried and tested ${ }^{6}$. Its strength is that it takes account not only of what has been shown to be possible, in term of claimant rates, in

\footnotetext{
${ }^{5}$ In practice, a number of the claimant unemployed fail to meet one or more of the ILO unemployment criteria so the number of ILO unemployed who are not included in the claimant count is larger than the difference between the two figures. For GB as a whole, Labour Force Survey data indicates that 200250,000 claimant unemployed fail to meet the ILO criteria.

${ }^{6}$ In addition to the earlier reports in this series, see C Beatty and S Fothergill (2005) 'The diversion from 'unemployment' to 'sickness' across British regions and districts', Regional Studies, vol 39, pp 837-854.
} 
fully-employed parts of Britain but also adjusts for underlying differences in the extent of incapacitating ill-health.

As a guide to differences in the incidence of incapacitating ill-health, the previous applications of this method used data from the 1981 Census which had the advantage of being uncontaminated by the subsequent surge in incapacity claimant numbers. With the passage of time, however, the value of such historic data becomes questionable. In the present report we therefore deploy a new method. Here, the benchmark incapacity claimant rate for each district is again the rate in fully-employed parts of southern England ${ }^{7}$ but here it is adjusted up or down by the ratio between the Standardised Mortality Rate (SMR) in each district $^{8}$ and the SMR in this fully-employed part of southern England. In effect, if the SMR in a district is 20 per cent above the level in fully-employed southern England we would expect the incapacity claimant rate to be 20 per cent higher.

Standardised Mortality Rates measure the death rate in each area after adjusting for the age structure of the local population. SMRs are widely regarded as the single most objective measure of health, and annual data is available for local authority districts. Ultimately, SMRs provide only a proxy for variations in incapacitating ill health or disability from place to place but they do provide a guide that is unaffected by benefit status, which is a clear risk affecting survey-based data on self-reported health and well-being.

This is an important revision to the method used to estimate hidden unemployment among incapacity claimants. For Britain as a whole in 2017, the new method generates an estimate of hidden unemployment that is 35,000 higher than the old method based on 1981 Census data. The use of SMR data does however take account of regional and local differences in the rate of health improvement in the intervening years.

Figure 2 shows the results of the application of this revised method to the incapacity claimant data for November 2016. It shows the estimated hidden unemployment on incapacity benefits in each local authority district, expressed as a percentage of the working age population (16-64). The map confirms the hidden unemployment is concentrated in particular parts of the country, above all in older industrial areas and seaside towns. There is little or no hidden unemployment of this kind in the more prosperous parts of country with stronger labour markets, especially in southern England.

Blackpool - a seaside town - has the very highest hidden unemployment on incapacity benefits, estimated at 7.1 per cent of the working age population ${ }^{9}$. Blackpool's tourist economy has flagged in recent years and the ready availability of cheap private-rented flats in the town, much of it in former guest houses, has attracted benefit claimants from surrounding areas and further afield. That Blackpool borough itself is the disadvantaged core of a rather larger built-up area also boosts the local claimant rate.

\footnotetext{
${ }^{7}$ Defined here and in earlier reports as Berkshire, Buckinghamshire, Hampshire (minus Portsmouth and Southampton), Hertfordshire, Oxfordshire, Surrey and West Sussex.

${ }^{8}$ In 2015. Source: ONS.

${ }^{9}$ At 12.9 per cent of the working age population, Blackpool also has the highest incapacity claimant rate in Great Britain.
} 
Figure 2: Estimated hidden unemployment on incapacity benefits, by district, November 2016

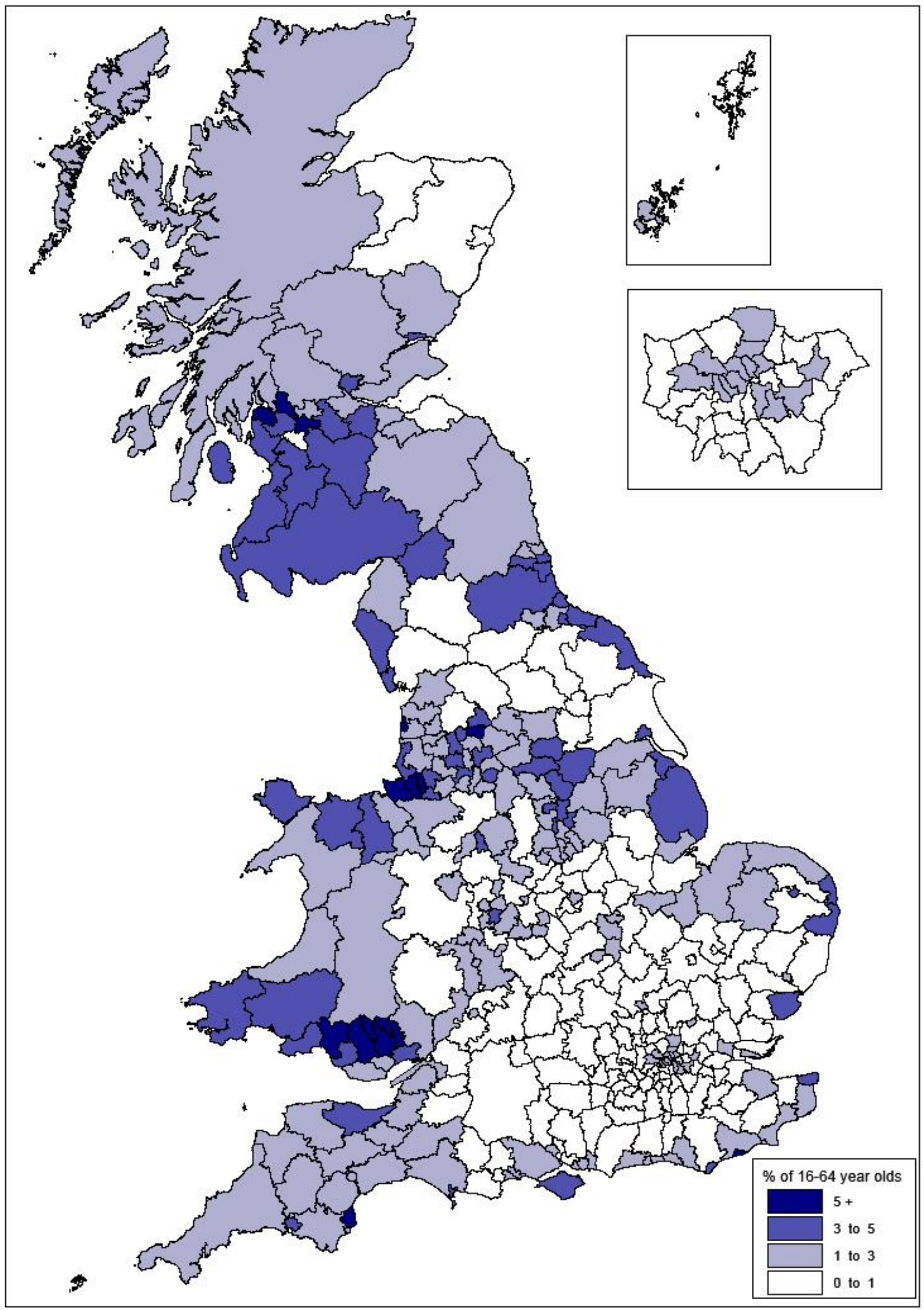

Source: Sheffield Hallam estimates based on ONS and DWP data 
Just behind Blackpool, with hidden unemployment on incapacity benefits estimated at 7 per cent of the working age population, are two South Wales districts hit by coal and steel job losses, Neath Port Talbot and Blaenau Gwent. They are closely followed by a long list of other older industrial areas including Liverpool (5.6 per cent) and Glasgow (5.4 per cent). Hastings, Torbay and Denbighshire (which covers Rhyl) are other seaside towns that have particularly high hidden unemployment rates.

The method deployed here to estimate hidden unemployment on incapacity benefits adjusts for the biggest single distortion to the official unemployment figures. It is nevertheless worth underlining that all the resulting figures remain estimates subject (like the government's own ILO unemployment data for local areas) to a residual margin of error. Additionally, there is likely to be some hidden unemployment even beyond the figures presented here, for example among men and women who do not claim benefits and fail to meet the ILO unemployment criteria, perhaps because they have despaired of looking for work. The figures presented here should therefore be regarded as a minimum estimate of the scale of unemployment.

\section{National overview}

The final column of Table 1 presents our estimates of the real level of unemployment across Great Britain as a whole in spring 2017.

Table 1: The real level of unemployment

\begin{tabular}{lrrrrr}
\hline & $\mathbf{1 9 9 7}$ & $\mathbf{2 0 0 2}$ & $\mathbf{2 0 0 7}$ & $\mathbf{2 0 1 2}$ & $\mathbf{2 0 1 7}$ \\
\hline Claimant count & $1,835,000$ & 980,000 & 940,000 & $1,555,000$ & 785,000 \\
Additional ILO unemployed & 315,000 & 470,000 & 650,000 & 985,000 & 735,000 \\
Hidden on incapacity benefits & $1,020,000$ & $1,150,000$ & $1,010,000$ & 900,000 & 760,000 \\
\hline REAL UNEMPLOYMENT & $\mathbf{3 , 1 8 0 , 0 0 0}$ & $\mathbf{2 , 6 0 0 , 0 0 0}$ & $\mathbf{2 , 6 0 0 , 0 0 0}$ & $\mathbf{3 , 4 4 0 , 0 0 0}$ & $\mathbf{2 , 2 8 0 , 0 0 0}$ \\
\hline
\end{tabular}

Sources: ONS, DWP and Sheffield Hallam estimates

Our estimate is that in 2017 the real level of unemployment stands at just below $\mathbf{2 . 3}$ million. This is made up almost equally of the claimant unemployed, the additional ILO unemployed and the hidden unemployed on incapacity benefits, each of whom contribute $700-800,000$ to the total. The 2.3 million represent an unemployment rate of 5.7 per cent of the working age population ${ }^{10}$.

\footnotetext{
${ }^{10}$ Official statistics express the unemployment rate as a percentage of the economically active (i.e. the employed plus the unemployed), which excludes the hidden unemployed from the denominator. Expressed as a percentage of the working age population, the claimant count in Table 1 represents a rate of 2.0 per cent, and ILO unemployment 3.8 per cent.
} 
We estimate that across Britain as a whole hidden unemployment on incapacity benefits accounts for 760,000 men and women. These are the claimants who might reasonably be expected to have been in work in a genuinely fully-employed economy. This large number needs to be seen in the context of the headline total of 2.45 million out-of-work on incapacity benefits. In effect, our figures suggest that around 1.7 million men and women would remain on incapacity benefits even if there were full employment across the whole country. The hidden unemployed are a minority of incapacity claimants (around 30 per cent) even though they are nearly as numerous as the claimant unemployed, and again it is worth emphasising that there is no suggestion here that the claims are in any way fraudulent or that the health problems or disabilities are anything less than real.

Table 1 also shows the corresponding estimates of unemployment from our four earlier studies. A health warning is necessary here: because a revised method has been adopted here the new estimates of hidden unemployment on incapacity benefits are not fully comparable with the figures for earlier years. Nevertheless, a number of points are worth noting.

First, at just under 2.3 million the real level of unemployment is lower than in any of the other four years, and more than 1.1 million down on the estimate for 2012. This is clear evidence of progress in reducing unemployment, though it is widely acknowledged that much of the recent job growth has been in low-paid and often insecure or part-time work, including selfemployment. Even so, a real unemployment level of 2.3 million hardly seems like full employment.

Second, hidden unemployment on incapacity benefits does appear to be falling. At an estimated 760,000 it is nearly 400,000 down on the peak recorded in 2002 . The reduction has been gradual since 2002 it seems, and perhaps not entirely unexpected given the tougher medical test, the wider application of means-testing, the new conditionality for some and the recent improvement in the wider labour market.

Third, the gap between claimant and ILO unemployment has also fallen since 2012, when it reached a peak of almost 1 million. Again, improving conditions in the labour market probably offer an explanation, but the number of additional ILO unemployed remains at a higher level than before the 2008 financial crisis.

\section{Regional differences}

Table 2 shows the estimated real unemployment by region and country across Great Britain. The North East of England tops this list with a rate of 8.6 per cent of the working age population - a very long way from full employment. At the other end of the spectrum, the rate in the South East of England is just 3.9 per cent ${ }^{11}$.

\footnotetext{
${ }^{11}$ The unemployment rates quoted here and subsequently for local areas, using the working age population as the denominator, are not comparable with official unemployment rates that use the (smaller) economically active population as the denominator.
} 
Table 2: The real level of unemployment by region and country, Spring 2017

\begin{tabular}{lrrrrr}
\hline & $\begin{array}{r}\text { Claimant } \\
\text { count }\end{array}$ & $\begin{array}{r}\text { Additional } \\
\text { ILO } \\
\text { unemployed }\end{array}$ & $\begin{array}{r}\text { Hidden } \\
\text { unemployed } \\
\text { on incapacity } \\
\text { benefits }\end{array}$ & No. & $\begin{array}{r}\text { \% of working } \\
\text { age }\end{array}$ \\
\hline North East & 53,200 & 38,100 & 52,000 & $\mathbf{1 4 3 , 0 0 0}$ & $\mathbf{8 . 6}$ \\
Wales & 40,700 & 24,500 & 76,000 & $\mathbf{1 4 1 , 0 0 0}$ & $\mathbf{7 . 4}$ \\
North West & 112,900 & 64,600 & 142,000 & $\mathbf{3 1 9 , 0 0 0}$ & $\mathbf{7 . 1}$ \\
Scotland & 82,700 & 39,200 & 98,000 & $\mathbf{2 1 9 , 0 0 0}$ & $\mathbf{6 . 3}$ \\
West Midlands & 87,600 & 64,500 & 73,000 & $\mathbf{2 2 5 , 0 0 0}$ & $\mathbf{6 . 3}$ \\
Yorkshire \& Humber & 77,200 & 54,400 & 76,000 & $\mathbf{2 0 8 , 0 0 0}$ & $\mathbf{6 . 1}$ \\
London & 124,600 & 153,200 & 58,000 & $\mathbf{3 3 6 , 0 0 0}$ & $\mathbf{5 . 6}$ \\
East Midlands & 47,000 & 52,800 & 50,000 & $\mathbf{1 5 0 , 0 0 0}$ & $\mathbf{5 . 1}$ \\
South West & 45,200 & 62,540 & 53,000 & $\mathbf{1 6 1 , 0 0 0}$ & $\mathbf{4 . 8}$ \\
East of England & 50,700 & 67,200 & 37,000 & $\mathbf{1 5 5 , 0 0 0}$ & $\mathbf{4 . 1}$ \\
South East & 65,000 & 112,100 & 42,000 & $\mathbf{2 1 9 , 0 0 0}$ & $\mathbf{3 . 9}$ \\
\hline Great Britain & $\mathbf{7 8 5 , 0 0 0}$ & $\mathbf{7 3 5 , 0 0 0}$ & $\mathbf{7 6 0 , 0 0 0}$ & $\mathbf{2 , 2 8 0 , 0 0 0}$ & $\mathbf{5 . 7}$ \\
\hline
\end{tabular}

Sources: ONS, DWP and Sheffield Hallam estimates

Hidden unemployment on incapacity benefits is concentrated in the regions with the highest real unemployment. In the six regions/countries at the top of the list in Table 2, where the labour market is weakest, the hidden unemployment on incapacity benefits exceeds the number of additional ILO unemployed, in some cases by a large margin. Conversely, in the five regions at the bottom of the list the number of additional ILO unemployed exceeds the hidden unemployed on incapacity benefits.

\section{Real unemployment at the local level}

Figure 3 shows the estimated real rate of unemployment by district. The full figures for each district are presented in the appendix. The unemployment rates here are all expressed as a percentage of the working age population. This differs from official statistics, which use the economically active population, which is smaller ${ }^{12}$.

The map shows how high unemployment remains a defining feature of the older industrial areas of northern and western Britain. Places such as the Welsh Valleys, Clydeside, Merseyside and the industrial North East stand out as having exceptionally high levels of

\footnotetext{
${ }^{12}$ The rates are not therefore comparable. However, as a rule of thumb the real unemployment rate in most districts, expressed as a percentage of the economically active, is around one-quarter higher than the levels in Figure 3 and Table 3.
} 
Figure 3: Estimated real unemployment by district, Spring 2017

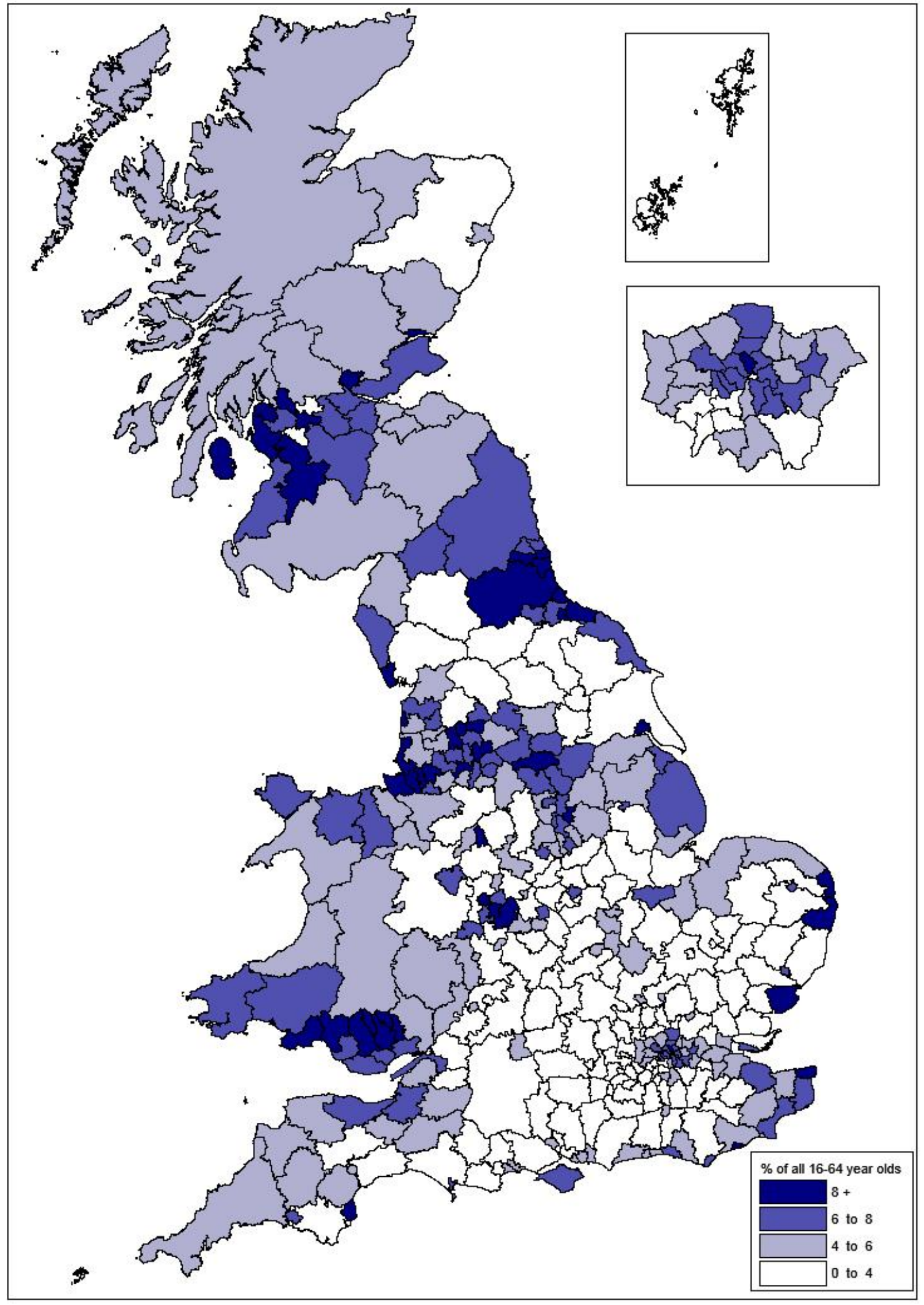

Source: Sheffield Hallam estimates based on ONS and DWP data 
unemployment. In this respect the figures here confirm what claimant unemployment data has been showing for many years, but the real unemployment data exposes the extent to which the problem in these places is far worse than official statistics have suggested. Unemployment in these parts of Britain typically remains in excess of 8 per cent, and in some cases above 10 per cent, of the entire working age population.

Britain's older industrial areas are joined by a number of coastal districts and some inner urban areas. Parts of London have high unemployment - though not quite as high as the older industrial areas of the North, Scotland and Wales - but London's unemployment tends to be concentrated in particular boroughs, which reflects residential segregation between the richer and poorer areas of the city.

On the other hand, there is little to suggest that unemployment is more than a marginal issue in large parts of southern and eastern England outside London. Some parts of northern England, such as rural North Yorkshire, also fall into this category. In these places, the real level of unemployment is typically below 4 per cent and sometimes nearer 2 per cent.

Table 3 lists the local authority districts with the highest and lowest real unemployment. Blackpool tops the list (as it does for hidden unemployment) with an estimated rate of 12.1 per cent of the working age population. Among the rest of the top fifty there are at least six clusters of adjoining districts:

North East (South Tyneside, Gateshead, Sunderland, County Durham, Hartlepool, Middlesbrough, Redcar \& Cleveland)

East Lancashire (Blackburn with Darwen, Hyndburn, Burnley)

Merseyside (Liverpool, Knowsley, Sefton, St Helens, Wirral)

Birmingham area (Birmingham, Sandwell, Wolverhampton)

Glasgow area (Glasgow, Inverclyde, West Dunbartonshire, North Ayrshire, East Ayrshire)

Welsh Valleys (Torfaen, Blaenau Gwent, Caerphilly, Merthyr Tydfil, Rhondda Cynon Taff, Bridgend, Neath Port Talbot, Swansea)

These extensive areas could claim to be Britain's main unemployment 'blackspots', though that is not to diminish the scale of the problem in other places with similar levels of unemployment such as Hull, Stoke-on-Trent, Barnsley and Dundee, or indeed seaside resorts such as Blackpool, Hastings, Great Yarmouth and Torbay. All these places have long been known to face unemployment problems. What the figures presented here demonstrate is that the problem is actually much larger than official unemployment statistics would suggest.

Indeed, the figures indicate that in several of these blackspots the hidden unemployment on incapacity benefits accounts for over half the total. In the Welsh Valleys this hidden unemployment is 60 per cent of the total, on Merseyside 58 per cent, in the Glasgow area 55 


\section{TOP 50 DISTRICTS}

1. Blackpool

2. Hartlepool

3. Blaenau Gwent

4. Merthyr Tydfil

5. Middlesbrough

6. South Tyneside

7. Neath Port Talbot

8. Knowsley

9. Inverclyde

10. Sunderland

11. Hastings

12. North Ayrshire

13. Liverpool

14. Great Yarmouth

15. Burnley

16. Rhondda Cynon Taf

17. Redcar \& Cleveland

18. Torbay

19. Glasgow

20. Hull

21. Stoke-on-Trent

22. West Dunbartonshire

23. Rochdale

24. Caerphilly

25. Birmingham

26. Clackmannanshire

27. Hyndburn

28. Blackburn with Darwen

29. County Durham

30. Torfaen

31. Sandwell

32. Barrow-in-Furness

33. Salford

34. Mansfield

35. Dundee

36. Wolverhampton

37. Gateshead

38. Sefton

39. East Ayrshire

(cont)

12.1

11.6

11.1

11.0

10.9

10.9

10.7

10.7

10.5

10.5

10.4

10.4

10.1

10.0

9.9

9.8

9.8

9.6

9.4

9.3

9.3

9.2

9.0

9.0

8.9

8.9

8.9

8.9

8.7

8.6

8.6

8.6

8.5

8.5

8.4

8.4

8.3

8.3

8.2

40. Barnsley

41. Swansea

42. Thanet

8.1

43. Tendring

8.1

44. Islington

8.1

45. Waveney

8.1

46. St Helens

8.1

47. Wirral

8.1

48. Bridgend

8.0

49. Weymouth \& Portland

7.9

50. Rotherham

\section{BOTTOM 20 DISTRICTS}

359. East Hertfordshire

360. Cotswold

361. Richmondshire

362. South Derbyshire

363. Wokingham

364. Vale of White Horse

365. South Oxfordshire

366. East Cambridgeshire

367. Test Valley

368. Rutland

369. Harborough

370. South Northamptonshire

371. Derbyshire Dales

372. Mid Sussex

373. Hart

374. Waverley

375. Shetland Islands

376. South Cambridgeshire

377. West Oxfordshire

378. Uttlesford 
per cent and in East Lancashire 52 per cent. It is a similar picture in some of the most disadvantaged seaside towns such as Blackpool (59 per cent), Hastings (54 per cent) and Torbay (57 per cent).

This concentration of hidden unemployment in the places with the weakest local labour markets is consistent with the view that where decent jobs are hardest to find, many men and women give up looking for work and therefore fail to meet the ILO unemployment criteria. The concentration of hidden unemployment in these places is also consistent with the view that in difficult labour markets the men and women with health problems or disabilities are especially disadvantaged in finding work and thereby boost the numbers claiming incapacity benefits. That said, the share of unemployment hidden on incapacity benefits also varies from place to place in ways that appear to reflect local factors such as the age structure of the local workforce (older men and women are more likely to claim incapacity benefits) and the robustness of the ILO unemployment estimates, which despite improvements still remain subject to sampling error.

The twenty places with the lowest real unemployment are a mixture of rural and suburban districts, mainly in southern England but also including the Shetland Islands in Scotland. Uttlesford, with the lowest real unemployment of all - just 1.9 per cent - is a district in Essex centred around the town of Saffron Waldon. These twenty districts, plus a number of others where the real unemployment rate is in the 2-3 per cent range, could legitimately claim to be operating at or close to full employment.

\section{Concluding remarks}

Unemployment, perhaps more than any other indicator, is the one by which the health of the economy is often judged. It is certainly the prime indicator in judging the economic health of local areas across the country.

It is unfortunate, therefore, that the official unemployment statistics provide such a partial view. As the evidence presented here demonstrates, the UK continues to hide large numbers of unemployed on incapacity benefits. The numbers of hidden unemployed have come down, but at an estimated 760,000 they are still more than big enough to cast a different light on the state of the labour market. Indeed, there are nearly as many hidden unemployed on incapacity benefits as there are visible unemployed on the claimant count. Unemployment has fallen over the last five years, but with the real level of unemployment still at around 2.3 million the claim that Britain is operating at or close to full employment is wide of the mark.

What the real unemployment data also shows is that big variations in the health of regional and local economies are still very much with us. Hidden unemployment tends to be concentrated in the weakest local labour markets. The effect of its inclusion in the figures is therefore to widen the gap between the best and worst areas across the country. Some parts of southern England do indeed seem to be fairly close to full employment, but that is emphatically not the case in most of the older industrial areas of the North, Midlands, Scotland and Wales, nor indeed in a number of seaside towns. 
APPENDIX: Estimated real level of unemployment by district, county, region and country, Spring 2017

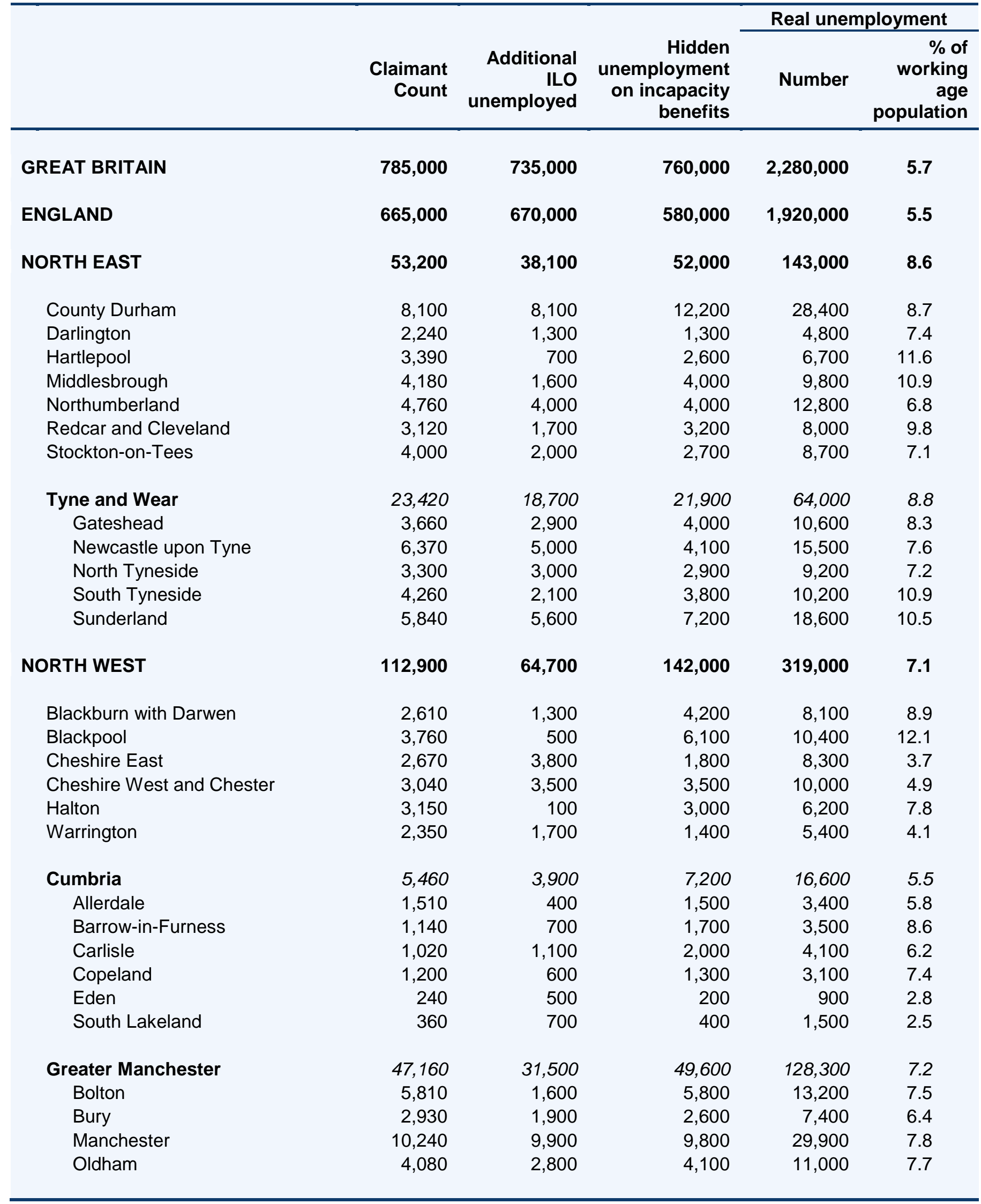




\begin{tabular}{|c|c|c|c|c|c|}
\hline & \multirow[b]{2}{*}{$\begin{array}{r}\text { Claimant } \\
\text { Count }\end{array}$} & \multirow[b]{2}{*}{$\begin{array}{r}\text { Additional } \\
\text { ILO } \\
\text { unemployed }\end{array}$} & \multirow[b]{2}{*}{$\begin{array}{r}\text { Hidden } \\
\text { unemployment } \\
\text { on incapacity } \\
\text { benefits }\end{array}$} & \multicolumn{2}{|c|}{ Real unemployment } \\
\hline & & & & Number & $\begin{array}{r}\% \text { of } \\
\text { working } \\
\text { age } \\
\text { population }\end{array}$ \\
\hline Rochdale & 4,250 & 2,300 & 5,700 & 12,200 & 9.0 \\
\hline Salford & 4,690 & 3,400 & 5,800 & 13,900 & 8.5 \\
\hline Stockport & 3,410 & 3,200 & 3,800 & 10,400 & 5.8 \\
\hline Tameside & 3,970 & 2,100 & 4,700 & 10,800 & 7.7 \\
\hline Trafford & 2,380 & 2,000 & 2,000 & 6,400 & 4.4 \\
\hline Wigan & 5,420 & 2,400 & 5,300 & 13,100 & 6.5 \\
\hline Lancashire & 15,390 & 11,600 & 17,700 & 44,700 & 6.1 \\
\hline Burnley & 1,840 & 800 & 2,700 & 5,300 & 9.9 \\
\hline Chorley & 1,130 & 1,200 & 1,000 & 3,300 & 4.6 \\
\hline Fylde & 680 & 600 & 800 & 2,100 & 4.6 \\
\hline Hyndburn & 1,370 & 700 & 2,300 & 4,400 & 8.9 \\
\hline Lancaster & 2,530 & 1,200 & 1,300 & 5,000 & 5.5 \\
\hline Pendle & 1,110 & 900 & 1,900 & 3,900 & 7.0 \\
\hline Preston & 2,170 & 1,600 & 2,600 & 6,400 & 6.8 \\
\hline Ribble Valley & 260 & 400 & 200 & 900 & 2.6 \\
\hline Rossendale & 910 & 800 & 1,300 & 3,000 & 6.8 \\
\hline South Ribble & 1,000 & 1,200 & 800 & 3,000 & 4.5 \\
\hline West Lancashire & 1,330 & 1,200 & 1,200 & 3,700 & 5.3 \\
\hline Wyre & 1,090 & 1,000 & 1,700 & 3,800 & 6.0 \\
\hline Merseyside & 27,290 & 6,700 & 47,400 & 81,400 & 9.1 \\
\hline Knowsley & 3,370 & 100 & 6,500 & 10,000 & 10.7 \\
\hline Liverpool & 11,990 & 3,000 & 18,400 & 33,400 & 10.1 \\
\hline Sefton & 4,370 & 1,600 & 7,600 & 13,600 & 8.3 \\
\hline St. Helens & 3,130 & 800 & 5,000 & 8,900 & 8.1 \\
\hline Wirral & 4,450 & 1,200 & 10,000 & 15,600 & 8.1 \\
\hline YORKSHIRE AND THE HUMBER & 77,200 & 54,400 & 76,000 & 208,000 & 6.1 \\
\hline East Riding of Yorkshire & 2,770 & 3,400 & 1,600 & 7,800 & 3.9 \\
\hline Kingston upon Hull & 6,360 & 2,700 & 6,800 & 15,900 & 9.3 \\
\hline North East Lincolnshire & 3,430 & 1,000 & 3,000 & 7,400 & 7.6 \\
\hline North Lincolnshire & 2,260 & 1,800 & 1,600 & 5,700 & 5.5 \\
\hline York & 1,020 & 2,400 & 100 & 3,500 & 2.5 \\
\hline North Yorkshire & 5,160 & 5,200 & 2,800 & 13,200 & 3.7 \\
\hline Craven & 440 & 500 & 200 & 1,100 & 3.2 \\
\hline Hambleton & 680 & 700 & 0 & 1,400 & 2.7 \\
\hline Harrogate & 1,310 & 1,400 & 0 & 2,700 & 2.9 \\
\hline Richmondshire & 460 & 300 & 0 & 800 & 2.4 \\
\hline Ryedale & 510 & 400 & 0 & 900 & 2.9 \\
\hline Scarborough & 1,090 & 900 & 2,500 & 4,500 & 7.3 \\
\hline Selby & 680 & 1,000 & 100 & 1,800 & 3.4 \\
\hline
\end{tabular}




\begin{tabular}{|c|c|c|c|c|c|}
\hline & \multirow[b]{2}{*}{$\begin{array}{r}\text { Claimant } \\
\text { Count }\end{array}$} & \multirow[b]{2}{*}{$\begin{array}{r}\text { Additional } \\
\text { ILO } \\
\text { unemployed }\end{array}$} & \multirow[b]{2}{*}{$\begin{array}{r}\text { Hidden } \\
\text { unemployment } \\
\text { on incapacity } \\
\text { benefits }\end{array}$} & \multicolumn{2}{|c|}{ Real unemployment } \\
\hline & & & & Number & $\begin{array}{r}\% \text { of } \\
\text { working } \\
\text { age } \\
\text { population }\end{array}$ \\
\hline South Yorkshire & 22,370 & 15,500 & 26,300 & 64,200 & 7.3 \\
\hline Barnsley & 3,560 & 2,400 & 6,400 & 12,400 & 8.2 \\
\hline Doncaster & 5,120 & 3,900 & 6,000 & 15,000 & 7.9 \\
\hline Rotherham & 4,180 & 3,000 & 5,600 & 12,800 & 7.9 \\
\hline Sheffield & 9,520 & 6,200 & 8,400 & 24,100 & 6.4 \\
\hline West Yorkshire & 33,820 & 22,300 & 33,700 & 89,800 & 6.2 \\
\hline Bradford & 9,130 & 5,700 & 8,400 & 23,200 & 7.0 \\
\hline Calderdale & 2,750 & 1,100 & 3,500 & 7,300 & 5.6 \\
\hline Kirklees & 5,950 & 4,900 & 5,800 & 16,600 & 6.1 \\
\hline Leeds & 11,820 & 6,500 & 8,600 & 26,900 & 5.2 \\
\hline Wakefield & 4,180 & 4,200 & 7,400 & 15,800 & 7.5 \\
\hline EAST MIDLANDS & 47,000 & 52,800 & 50,000 & 150,000 & 5.1 \\
\hline Derby & 2,820 & 2,200 & 4,800 & 9,800 & 6.0 \\
\hline Leicester & 4,180 & 4,600 & 5,900 & 14,700 & 6.3 \\
\hline Nottingham & 7,370 & 3,900 & 6,300 & 17,600 & 7.8 \\
\hline Rutland & 140 & 400 & 0 & 500 & 2.2 \\
\hline Derbyshire & 6,390 & 8,100 & 9,300 & 23,800 & 4.9 \\
\hline Amber Valley & 990 & 1,100 & 1,200 & 3,300 & 4.3 \\
\hline Bolsover & 720 & 1,000 & 1,600 & 3,300 & 6.8 \\
\hline Chesterfield & 1,280 & 1,100 & 2,800 & 5,200 & 7.9 \\
\hline Derbyshire Dales & 230 & 700 & 0 & 900 & 2.2 \\
\hline Erewash & 1,220 & 1,000 & 1,500 & 3,700 & 5.2 \\
\hline High Peak & 630 & 1,200 & 800 & 2,600 & 4.6 \\
\hline North East Derbyshire & 870 & 1,000 & 1,400 & 3,300 & 5.6 \\
\hline South Derbyshire & 460 & 1,000 & 0 & 1,500 & 2.4 \\
\hline Leicestershire & 3,620 & 7,800 & 1,700 & 13,100 & 3.1 \\
\hline Blaby & 450 & 1,100 & 100 & 1,600 & 2.7 \\
\hline Charnwood & 900 & 2,400 & 900 & 4,200 & 3.5 \\
\hline Harborough & 330 & 900 & 0 & 1,200 & 2.2 \\
\hline Hinckley and Bosworth & 700 & 1,100 & 200 & 2,000 & 3.0 \\
\hline Melton & 450 & 600 & 0 & 1,000 & 3.2 \\
\hline North West Leicestershire & 520 & 1,100 & 400 & 2,000 & 3.3 \\
\hline Oadby and Wigston & 290 & 700 & 100 & 1,100 & 3.3 \\
\hline Lincolnshire & 7,270 & 7,900 & 7,700 & 22,900 & 5.1 \\
\hline Boston & 670 & 800 & 600 & 2,100 & 5.2 \\
\hline East Lindsey & 1,520 & 1,300 & 3,300 & 6,100 & 7.9 \\
\hline Lincoln & 1,630 & 1,200 & 1,400 & 4,200 & 6.3 \\
\hline North Kesteven & 650 & 1,400 & 300 & 2,300 & 3.5 \\
\hline South Holland & 690 & 1,000 & 400 & 2,100 & 3.9 \\
\hline South Kesteven & 1,100 & 1,400 & 400 & 2,900 & 3.5 \\
\hline West Lindsey & 1,020 & 900 & 1,200 & 3,100 & 5.6 \\
\hline
\end{tabular}




\begin{tabular}{|c|c|c|c|c|c|}
\hline & \multirow[b]{2}{*}{$\begin{array}{r}\text { Claimant } \\
\text { Count }\end{array}$} & \multirow[b]{2}{*}{$\begin{array}{r}\text { Additional } \\
\text { ILO } \\
\text { unemployed }\end{array}$} & \multirow[b]{2}{*}{$\begin{array}{r}\text { Hidden } \\
\text { unemployment } \\
\text { on incapacity } \\
\text { benefits }\end{array}$} & \multicolumn{2}{|c|}{ Real unemployment } \\
\hline & & & & Number & $\begin{array}{r}\% \text { of } \\
\text { working } \\
\text { age } \\
\text { population }\end{array}$ \\
\hline Northamptonshire & 7,160 & 8,300 & 3,900 & 19,400 & 4.3 \\
\hline Corby & 880 & 700 & 800 & 2,400 & 5.5 \\
\hline Daventry & 800 & 800 & 0 & 1,600 & 3.2 \\
\hline East Northamptonshire & 580 & 1,000 & 0 & 1,600 & 2.9 \\
\hline Kettering & 1,060 & 1,100 & 800 & 3,000 & 5.0 \\
\hline Northampton & 2,660 & 2,600 & 1,500 & 6,800 & 4.7 \\
\hline South Northamptonshire & 310 & 900 & 0 & 1,200 & 2.2 \\
\hline Wellingborough & 900 & 1,100 & 800 & 2,800 & 6.0 \\
\hline Nottinghamshire & 8,050 & 9,600 & 10,000 & 27,600 & 5.5 \\
\hline Ashfield & 1,560 & 1,200 & 2,300 & 5,100 & 6.5 \\
\hline Bassetlaw & 1,150 & 1,300 & 1,700 & 4,100 & 5.9 \\
\hline Broxtowe & 1,130 & 1,200 & 800 & 3,100 & 4.4 \\
\hline Gedling & 1,170 & 1,500 & 900 & 3,600 & 5.0 \\
\hline Mansfield & 1,430 & 1,400 & 2,900 & 5,700 & 8.5 \\
\hline Newark and Sherwood & 990 & 1,600 & 1,400 & 4,000 & 5.6 \\
\hline Rushcliffe & 640 & 1,400 & 0 & 2,000 & 2.8 \\
\hline WEST MIDLANDS & 87,600 & 64,500 & 73,000 & 225,000 & 6.3 \\
\hline Herefordshire & 1,150 & 2,300 & 1,100 & 4,500 & 4.0 \\
\hline Shropshire & 2,040 & 3,100 & 1,400 & 6,500 & 3.5 \\
\hline Stoke-on-Trent & 3,860 & 3,100 & 7,800 & 14,800 & 9.3 \\
\hline Telford and Wrekin & 2,020 & 2,200 & 2,900 & 7,100 & 6.5 \\
\hline Staffordshire & 5,710 & 10,600 & 6,500 & 22,800 & 4.3 \\
\hline Cannock Chase & 830 & 1,500 & 1,100 & 3,400 & 5.5 \\
\hline East Staffordshire & 790 & 1,600 & 900 & 3,300 & 4.5 \\
\hline Lichfield & 450 & 1,000 & 400 & 1,800 & 2.9 \\
\hline Newcastle-under-Lyme & 1,120 & 1,700 & 1,600 & 4,400 & 5.3 \\
\hline South Staffordshire & 770 & 1,200 & 0 & 2,000 & 3.0 \\
\hline Stafford & 790 & 1,600 & 800 & 3,200 & 3.9 \\
\hline Staffordshire Moorlands & 500 & 1,000 & 700 & 2,200 & 3.8 \\
\hline Tamworth & 480 & 1,000 & 1,100 & 2,600 & 5.3 \\
\hline Warwickshire & 4,380 & 6,000 & 2,000 & 12,400 & 3.6 \\
\hline North Warwickshire & 440 & 700 & 100 & 1,200 & 3.2 \\
\hline Nuneaton and Bedworth & 1,470 & 1,600 & 1,600 & 4,700 & 6.0 \\
\hline Rugby & 1,330 & 1,000 & 0 & 2,300 & 3.6 \\
\hline Stratford-on-Avon & 510 & 1,200 & 0 & 1,700 & 2.5 \\
\hline Warwick & 640 & 1,600 & 200 & 2,400 & 2.7 \\
\hline West Midlands County & 64,000 & 30,500 & 46,500 & 141,000 & 7.8 \\
\hline Birmingham & 32,210 & 11,200 & 21,200 & 64,600 & 8.9 \\
\hline Coventry & 4,460 & 4,000 & 4,200 & 12,700 & 5.4 \\
\hline Dudley & 5,830 & 3,400 & 3,800 & 13,000 & 6.7 \\
\hline Sandwell & 7,240 & 3,900 & 6,200 & 17,300 & 8.6 \\
\hline
\end{tabular}




\begin{tabular}{|c|c|c|c|c|c|}
\hline & \multirow[b]{2}{*}{$\begin{array}{r}\text { Claimant } \\
\text { Count }\end{array}$} & \multirow[b]{2}{*}{$\begin{array}{r}\text { Additional } \\
\text { ILO } \\
\text { unemployed }\end{array}$} & \multirow[b]{2}{*}{$\begin{array}{r}\text { Hidden } \\
\text { unemployment } \\
\text { on incapacity } \\
\text { benefits }\end{array}$} & \multicolumn{2}{|c|}{ Real unemployment } \\
\hline & & & & Number & $\begin{array}{r}\% \text { of } \\
\text { working } \\
\text { age } \\
\text { population }\end{array}$ \\
\hline Solihull & 2,320 & 3,400 & 1,700 & 7,400 & 5.9 \\
\hline Walsall & 5,040 & 2,800 & 4,700 & 12,500 & 7.4 \\
\hline Wolverhampton & 6,920 & 1,900 & 4,700 & 13,500 & 8.4 \\
\hline Worcestershire & 4,510 & 6,700 & 5,000 & 16,200 & 4.6 \\
\hline Bromsgrove & 640 & 1,000 & 0 & 1,600 & 2.8 \\
\hline Malvern Hills & 430 & 1,000 & 500 & 1,900 & 4.5 \\
\hline Redditch & 930 & 1,100 & 900 & 2,900 & 5.4 \\
\hline Worcester & 1,000 & 1,300 & 1,000 & 3,300 & 5.0 \\
\hline Wychavon & 690 & 1,300 & 800 & 2,800 & 3.9 \\
\hline Wyre Forest & 830 & 1,100 & 1,700 & 3,600 & 6.2 \\
\hline EAST & 50,700 & 67,200 & 37,000 & 155,000 & 4.1 \\
\hline Bedford & 2,230 & 2,000 & 900 & 5,100 & 4.9 \\
\hline Central Bedfordshire & 1,420 & 3,100 & 0 & 4,500 & 2.6 \\
\hline Luton & 2,760 & 2,700 & 1,900 & 7,400 & 5.3 \\
\hline Peterborough & 1,770 & 2,700 & 3,400 & 7,900 & 6.4 \\
\hline Southend-on-Sea & 2,360 & 1,800 & 2,700 & 6,900 & 6.2 \\
\hline Thurrock & 2,100 & 2,200 & 300 & 4,600 & 4.3 \\
\hline Cambridgeshire & 2,800 & 6,900 & 1,800 & 11,500 & 2.8 \\
\hline Cambridge & 700 & 1,800 & 0 & 2,500 & 2.6 \\
\hline East Cambridgeshire & 300 & 900 & 0 & 1,200 & 2.3 \\
\hline Fenland & 670 & 1,000 & 1,600 & 3,300 & 5.4 \\
\hline Huntingdonshire & 710 & 1,700 & 300 & 2,700 & 2.4 \\
\hline South Cambridgeshire & 430 & 1,500 & 0 & 1,900 & 2.0 \\
\hline Essex & 11,970 & 16,000 & 7,200 & 35,200 & 4.0 \\
\hline Basildon & 2,090 & 2,400 & 1,900 & 6,400 & 5.6 \\
\hline Braintree & 1,000 & 1,800 & 100 & 2,900 & 3.1 \\
\hline Brentwood & 400 & 900 & 0 & 1,300 & 2.8 \\
\hline Castle Point & 650 & 1,000 & 300 & 1,900 & 3.6 \\
\hline Chelmsford & 1,210 & 1,700 & 0 & 2,900 & 2.7 \\
\hline Colchester & 1,410 & 2,400 & 800 & 4,600 & 3.8 \\
\hline Epping Forest & 970 & 1,500 & 0 & 2,500 & 3.1 \\
\hline Harlow & 1,030 & 1,000 & 900 & 2,900 & 5.4 \\
\hline Maldon & 370 & 800 & 0 & 1,200 & 3.2 \\
\hline Rochford & 460 & 800 & 0 & 1,300 & 2.5 \\
\hline Tendring & 2,140 & 1,000 & 3,200 & 6,300 & 8.1 \\
\hline Uttlesford & 260 & 700 & 0 & 1,000 & 1.9 \\
\hline
\end{tabular}




\begin{tabular}{|c|c|c|c|c|c|}
\hline & \multirow[b]{2}{*}{$\begin{array}{r}\text { Claimant } \\
\text { Count }\end{array}$} & \multirow[b]{2}{*}{$\begin{array}{r}\text { Additional } \\
\text { ILO } \\
\text { unemployed }\end{array}$} & \multirow[b]{2}{*}{$\begin{array}{r}\text { Hidden } \\
\text { unemployment } \\
\text { on incapacity } \\
\text { benefits }\end{array}$} & \multicolumn{2}{|c|}{ Real unemployment } \\
\hline & & & & Number & $\begin{array}{r}\% \text { of } \\
\text { working } \\
\text { age } \\
\text { population }\end{array}$ \\
\hline Hertfordshire & 8,340 & 13,100 & 1,500 & 22,900 & 3.1 \\
\hline Broxbourne & 740 & 1,100 & 500 & 2,300 & 3.9 \\
\hline Dacorum & 1,180 & 1,500 & 200 & 2,900 & 3.0 \\
\hline East Hertfordshire & 650 & 1,600 & 0 & 2,200 & 2.4 \\
\hline Hertsmere & 770 & 900 & 300 & 2,000 & 3.1 \\
\hline North Hertfordshire & 960 & 1,500 & 0 & 2,500 & 3.0 \\
\hline St Albans & 810 & 1,600 & 0 & 2,400 & 2.7 \\
\hline Stevenage & 890 & 1,000 & 500 & 2,400 & 4.2 \\
\hline Three Rivers & 550 & 1,100 & 0 & 1,600 & 2.8 \\
\hline Watford & 930 & 1,100 & 0 & 2,000 & 3.2 \\
\hline Welwyn Hatfield & 880 & 1,700 & 100 & 2,700 & 3.3 \\
\hline Norfolk & 8,280 & 9,000 & 11,400 & 28,700 & 5.4 \\
\hline Breckland & 920 & 1,400 & 900 & 3,200 & 4.0 \\
\hline Broadland & 560 & 1,200 & 500 & 2,300 & 3.0 \\
\hline Great Yarmouth & 2,960 & 300 & 2,500 & 5,800 & 10.0 \\
\hline King's Lynn and West Norfolk & 900 & 1,700 & 2,300 & 4,900 & 5.6 \\
\hline North Norfolk & 530 & 900 & 1,400 & 2,800 & 5.0 \\
\hline Norwich & 1,760 & 2,100 & 3,400 & 7,300 & 7.5 \\
\hline South Norfolk & 660 & 1,300 & 500 & 2,500 & 3.2 \\
\hline Suffolk & 6,750 & 7,600 & 5,500 & 19,800 & 4.5 \\
\hline Babergh & 430 & 1,000 & 100 & 1,500 & 3.0 \\
\hline Forest Heath & 340 & 600 & 100 & 1,000 & 2.6 \\
\hline Ipswich & 1,830 & 1,800 & 2,000 & 5,600 & 6.4 \\
\hline Mid Suffolk & 490 & 1,200 & 0 & 1,700 & 2.9 \\
\hline St Edmundsbury & 790 & 1,000 & 600 & 2,400 & 3.6 \\
\hline Suffolk Coastal & 490 & 1,300 & 400 & 2,200 & 3.2 \\
\hline Waveney & 2,380 & 700 & 2,200 & 5,300 & 8.1 \\
\hline LONDON & 124,600 & 153,200 & 58,000 & 336,000 & 5.6 \\
\hline Camden & 2,810 & 5,100 & 4,700 & 12,600 & 7.2 \\
\hline Hackney & 4,980 & 4,900 & 4,600 & 14,500 & 7.4 \\
\hline Hammersmith and Fulham & 4,080 & 2,300 & 1,500 & 7,900 & 6.1 \\
\hline Haringey & 4,850 & 3,800 & 3,900 & 12,500 & 6.3 \\
\hline Islington & 3,760 & 5,900 & 4,500 & 14,200 & 8.1 \\
\hline Kensington and Chelsea & 1,880 & 3,600 & 2,300 & 7,800 & 7.3 \\
\hline Lambeth & 6,030 & 5,700 & 2,000 & 13,700 & 5.6 \\
\hline Lewisham & 5,410 & 4,500 & 3,100 & 13,000 & 6.2 \\
\hline Newham & 4,760 & 5,700 & 1,400 & 11,900 & 5.0 \\
\hline Southwark & 7,100 & 5,300 & 2,700 & 15,100 & 6.6 \\
\hline Tower Hamlets & 5,250 & 9,700 & 2,000 & 16,900 & 7.5 \\
\hline Wandsworth & 3,290 & 5,800 & 0 & 9,100 & 4.0 \\
\hline Westminster & 2,590 & 5,100 & 3,800 & 11,500 & 6.4 \\
\hline Barking and Dagenham & 3,260 & 4,100 & 1,800 & 9,200 & 7.1 \\
\hline Barnet & 3,640 & 6,400 & 1,800 & 11,800 & 4.7 \\
\hline Bexley & 2,190 & 3,900 & 500 & 6,600 & 4.3 \\
\hline
\end{tabular}




\begin{tabular}{|c|c|c|c|c|c|}
\hline & \multirow[b]{2}{*}{$\begin{array}{r}\text { Claimant } \\
\text { Count }\end{array}$} & \multirow[b]{2}{*}{$\begin{array}{r}\text { Additional } \\
\text { ILO } \\
\text { unemployed }\end{array}$} & \multirow[b]{2}{*}{$\begin{array}{r}\text { Hidden } \\
\text { unemployment } \\
\text { on incapacity } \\
\text { benefits }\end{array}$} & \multicolumn{2}{|c|}{ Real unemployment } \\
\hline & & & & Number & $\begin{array}{r}\% \text { of } \\
\text { working } \\
\text { age } \\
\text { population }\end{array}$ \\
\hline Brent & 5,260 & 6,700 & 3,000 & 15,000 & 6.8 \\
\hline Bromley & 2,400 & 4,400 & 1,300 & 8,100 & 4.0 \\
\hline Croydon & 9,110 & 4,500 & 1,100 & 14,700 & 5.9 \\
\hline Ealing & 5,190 & 4,700 & 2,900 & 12,800 & 5.6 \\
\hline Enfield & 4,720 & 5,700 & 3,300 & 13,700 & 6.4 \\
\hline Greenwich & 4,250 & 5,100 & 2,900 & 12,200 & 6.4 \\
\hline Harrow & 1,930 & 4,700 & 900 & 7,500 & 4.7 \\
\hline Havering & 2,690 & 3,700 & 700 & 7,100 & 4.5 \\
\hline Hillingdon & 2,720 & 5,300 & 100 & 8,100 & 4.1 \\
\hline Hounslow & 5,240 & 4,700 & 0 & 9,900 & 5.4 \\
\hline Kingston upon Thames & 1,360 & 2,900 & 0 & 4,300 & 3.6 \\
\hline Merton & 2,470 & 2,900 & 0 & 5,400 & 3.9 \\
\hline Redbridge & 2,670 & 5,400 & 0 & 8,100 & 4.2 \\
\hline Richmond upon Thames & 1,510 & 3,300 & 0 & 4,800 & 3.8 \\
\hline Sutton & 2,990 & 2,700 & 0 & 5,700 & 4.4 \\
\hline Waltham Forest & 4,200 & 4,700 & 1,600 & 10,500 & 5.6 \\
\hline SOUTH EAST & 65,000 & 112,100 & 42,000 & 219,000 & 3.9 \\
\hline Bracknell Forest & 640 & 1,400 & 0 & 2,000 & 2.6 \\
\hline Brighton and Hove & 3,030 & 6,200 & 4,300 & 13,500 & 6.6 \\
\hline Isle of Wight & 1,460 & 1,500 & 2,800 & 5,800 & 7.3 \\
\hline Medway & 3,470 & 4,200 & 1,600 & 9,300 & 5.2 \\
\hline Milton Keynes & 2,790 & 2,800 & 500 & 6,100 & 3.6 \\
\hline Portsmouth & 2,390 & 3,800 & 1,700 & 7,900 & 5.4 \\
\hline Reading & 1,820 & 1,800 & 400 & 4,000 & 3.7 \\
\hline Slough & 1,360 & 1,900 & 400 & 3,700 & 3.9 \\
\hline Southampton & 2,580 & 4,200 & 2,900 & 9,700 & 5.5 \\
\hline West Berkshire & 680 & 1,900 & 0 & 2,600 & 2.7 \\
\hline Windsor and Maidenhead & 770 & 1,800 & 0 & 2,600 & 2.8 \\
\hline Wokingham & 620 & 1,700 & 0 & 2,300 & 2.3 \\
\hline Buckinghamshire & 3,030 & 6,400 & 0 & 9,400 & 2.9 \\
\hline Aylesbury Vale & 1,060 & 2,400 & 0 & 3,500 & 2.9 \\
\hline Chiltern & 410 & 1,100 & 0 & 1,500 & 2.7 \\
\hline South Bucks & 310 & 700 & 0 & 1,000 & 2.4 \\
\hline Wycombe & 1,250 & 2,200 & 0 & 3,400 & 3.1 \\
\hline East Sussex & 5,010 & 6,100 & 8,400 & 19,500 & 6.2 \\
\hline Eastbourne & 1,170 & 1,200 & 2,400 & 4,800 & 7.9 \\
\hline Hastings & 1,810 & 900 & 3,200 & 5,900 & 10.4 \\
\hline Lewes & 710 & 1,300 & 1,200 & 3,200 & 5.4 \\
\hline Rother & 700 & 900 & 1,300 & 2,900 & 5.7 \\
\hline Wealden & 630 & 1,800 & 400 & 2,800 & 3.1 \\
\hline
\end{tabular}




\begin{tabular}{|c|c|c|c|c|c|}
\hline & \multirow[b]{2}{*}{$\begin{array}{r}\text { Claimant } \\
\text { Count }\end{array}$} & \multirow[b]{2}{*}{$\begin{array}{r}\text { Additional } \\
\text { ILO } \\
\text { unemployed }\end{array}$} & \multirow[b]{2}{*}{$\begin{array}{r}\text { Hidden } \\
\text { unemployment } \\
\text { on incapacity } \\
\text { benefits }\end{array}$} & \multicolumn{2}{|c|}{ Real unemployment } \\
\hline & & & & Number & $\begin{array}{r}\% \text { of } \\
\text { working } \\
\text { age } \\
\text { population }\end{array}$ \\
\hline Hampshire & 6,550 & 15,600 & 3,900 & 26,000 & 3.1 \\
\hline Basingstoke and Deane & 970 & 1,900 & 0 & 2,900 & 2.6 \\
\hline East Hampshire & 420 & 1,600 & 0 & 2,000 & 2.9 \\
\hline Eastleigh & 550 & 1,700 & 100 & 2,300 & 2.8 \\
\hline Fareham & 450 & 1,400 & 0 & 1,800 & 2.6 \\
\hline Gosport & 640 & 1,100 & 800 & 2,500 & 4.7 \\
\hline Hart & 280 & 900 & 0 & 1,200 & 2.1 \\
\hline Havant & 1,120 & 1,500 & 1,700 & 4,300 & 5.9 \\
\hline New Forest & 680 & 1,800 & 1,100 & 3,600 & 3.6 \\
\hline Rushmoor & 590 & 1,200 & 100 & 1,900 & 3.0 \\
\hline Test Valley & 480 & 1,100 & 0 & 1,600 & 2.2 \\
\hline Winchester & 400 & 1,400 & 0 & 1,800 & 2.4 \\
\hline Kent & 15,630 & 19,800 & 9,900 & 45,300 & 4.8 \\
\hline Ashford & 1,270 & 1,600 & 500 & 3,400 & 4.5 \\
\hline Canterbury & 1,270 & 2,300 & 700 & 4,300 & 4.1 \\
\hline Dartford & 810 & 1,600 & 0 & 2,400 & 3.5 \\
\hline Dover & 1,520 & 1,400 & 1,300 & 4,200 & 6.2 \\
\hline Gravesham & 1,370 & 1,900 & 500 & 3,800 & 5.8 \\
\hline Maidstone & 1,290 & 2,200 & 400 & 3,900 & 3.8 \\
\hline Sevenoaks & 510 & 1,300 & 0 & 1,800 & 2.6 \\
\hline Shepway & 1,430 & 1,100 & 1,700 & 4,200 & 6.4 \\
\hline Swale & 1,970 & 2,500 & 1,600 & 6,100 & 6.9 \\
\hline Thanet & 2,860 & 800 & 2,900 & 6,600 & 8.1 \\
\hline Tonbridge and Malling & 730 & 1,800 & 0 & 2,500 & 3.3 \\
\hline Tunbridge Wells & 630 & 1,200 & 200 & 2,000 & 2.8 \\
\hline Oxfordshire & 2,960 & 7,900 & 300 & 11,200 & 2.6 \\
\hline Cherwell & 560 & 1,900 & 100 & 2,600 & 2.8 \\
\hline Oxford & 1,110 & 2,300 & 200 & 3,600 & 3.1 \\
\hline South Oxfordshire & 430 & 1,500 & 0 & 1,900 & 2.3 \\
\hline Vale of White Horse & 460 & 1,300 & 0 & 1,800 & 2.3 \\
\hline West Oxfordshire & 420 & 900 & 0 & 1,300 & 2.0 \\
\hline Surrey & 5,060 & 13,600 & 100 & 18,800 & 2.6 \\
\hline Elmbridge & 480 & 1,400 & 0 & 1,900 & 2.4 \\
\hline Epsom and Ewell & 380 & 900 & 0 & 1,300 & 2.6 \\
\hline Guildford & 550 & 2,100 & 0 & 2,600 & 2.7 \\
\hline Mole Valley & 300 & 1,000 & 100 & 1,400 & 2.7 \\
\hline Reigate and Banstead & 740 & 1,700 & 0 & 2,400 & 2.7 \\
\hline Runnymede & 380 & 1,100 & 0 & 1,500 & 2.6 \\
\hline Spelthorne & 640 & 1,400 & 0 & 2,000 & 3.2 \\
\hline Surrey Heath & 340 & 1,100 & 0 & 1,400 & 2.6 \\
\hline Tandridge & 480 & 900 & 0 & 1,400 & 2.7 \\
\hline Waverley & 400 & 1,100 & 0 & 1,500 & 2.1 \\
\hline Woking & 410 & 1,000 & 100 & 1,500 & 2.4 \\
\hline
\end{tabular}




\begin{tabular}{|c|c|c|c|c|c|}
\hline & \multirow[b]{2}{*}{$\begin{array}{r}\text { Claimant } \\
\text { Count }\end{array}$} & \multirow[b]{2}{*}{$\begin{array}{r}\text { Additional } \\
\text { ILO } \\
\text { unemployed }\end{array}$} & \multirow[b]{2}{*}{$\begin{array}{r}\text { Hidden } \\
\text { unemployment } \\
\text { on incapacity } \\
\text { benefits }\end{array}$} & \multicolumn{2}{|c|}{ Real unemployment } \\
\hline & & & & Number & $\begin{array}{r}\% \text { of } \\
\text { working } \\
\text { age } \\
\text { population }\end{array}$ \\
\hline West Sussex & 5,210 & 9,400 & 4,500 & 19,100 & 3.8 \\
\hline Adur & 520 & 800 & 600 & 1,900 & 5.1 \\
\hline Arun & 1,130 & 1,700 & 1,900 & 4,700 & 5.3 \\
\hline Chichester & 720 & 1,000 & 200 & 1,900 & 2.8 \\
\hline Crawley & 950 & 1,800 & 700 & 3,400 & 4.6 \\
\hline Horsham & 610 & 1,500 & 0 & 2,100 & 2.6 \\
\hline Mid Sussex & 410 & 1,500 & 0 & 1,900 & 2.1 \\
\hline Worthing & 880 & 1,200 & 1,200 & 3,300 & 5.1 \\
\hline SOUTH WEST & 45,200 & 62,500 & 53,000 & 161,000 & 4.8 \\
\hline Bath and North East Somerset & 2,030 & 2,100 & 0 & 4,100 & 3.4 \\
\hline Bournemouth & 2,130 & 2,300 & 3,200 & 7,600 & 5.8 \\
\hline Bristol & 5,420 & 6,400 & 7,200 & 19,000 & 6.1 \\
\hline Cornwall & 4,590 & 5,600 & 8,700 & 18,900 & 5.8 \\
\hline North Somerset & 1,270 & 2,000 & 2,600 & 5,900 & 4.8 \\
\hline Plymouth & 3,750 & 3,300 & 6,100 & 13,100 & 7.7 \\
\hline Poole & 1,070 & 1,700 & 700 & 3,500 & 3.9 \\
\hline South Gloucestershire & 1,600 & 3,200 & 300 & 5,100 & 2.9 \\
\hline Swindon & 2,520 & 2,500 & 1,100 & 6,100 & 4.4 \\
\hline Torbay & 1,600 & 1,600 & 4,200 & 7,400 & 9.6 \\
\hline Wiltshire & 2,720 & 5,600 & 600 & 8,900 & 3.0 \\
\hline Devon & 4,340 & 9,300 & 6,700 & 20,300 & 4.4 \\
\hline East Devon & 660 & 1,300 & 800 & 2,800 & 3.7 \\
\hline Exeter & 920 & 2,500 & 1,000 & 4,400 & 4.9 \\
\hline Mid Devon & 460 & 800 & 500 & 1,800 & 3.8 \\
\hline North Devon & 560 & 900 & 1,100 & 2,600 & 4.7 \\
\hline South Hams & 350 & 800 & 600 & 1,700 & 3.5 \\
\hline Teignbridge & 690 & 1,600 & 1,300 & 3,600 & 4.8 \\
\hline Torridge & 470 & 800 & 900 & 2,200 & 5.7 \\
\hline West Devon & 240 & 500 & 600 & 1,300 & 4.1 \\
\hline Dorset & 2,020 & 4,000 & 3,600 & 9,600 & 4.1 \\
\hline Christchurch & 260 & 400 & 500 & 1,200 & 4.5 \\
\hline East Dorset & 330 & 900 & 200 & 1,400 & 2.9 \\
\hline North Dorset & 260 & 500 & 300 & 1,100 & 2.6 \\
\hline Purbeck & 220 & 400 & 200 & 800 & 2.9 \\
\hline West Dorset & 380 & 1,000 & 800 & 2,200 & 3.9 \\
\hline Weymouth and Portland & 590 & 700 & 1,800 & 3,100 & 7.9 \\
\hline Gloucestershire & 4,160 & 7,300 & 3,600 & 15,100 & 3.9 \\
\hline Cheltenham & 830 & 1,500 & 600 & 2,900 & 3.9 \\
\hline Cotswold & 360 & 800 & 0 & 1,200 & 2.4 \\
\hline Forest of Dean & 650 & 1,200 & 900 & 2,700 & 5.3 \\
\hline Gloucester & 1,320 & 1,700 & 1,600 & 4,600 & 5.7 \\
\hline Stroud & 510 & 1,200 & 300 & 2,000 & 2.8 \\
\hline Tewkesbury & 510 & 1,000 & 100 & 1,600 & 3.0 \\
\hline
\end{tabular}




\begin{tabular}{|c|c|c|c|c|c|}
\hline & \multirow[b]{2}{*}{$\begin{array}{r}\text { Claimant } \\
\text { Count }\end{array}$} & \multirow[b]{2}{*}{$\begin{array}{r}\text { Additional } \\
\text { ILO } \\
\text { unemployed }\end{array}$} & \multirow[b]{2}{*}{$\begin{array}{r}\text { Hidden } \\
\text { unemployment } \\
\text { on incapacity } \\
\text { benefits }\end{array}$} & \multicolumn{2}{|c|}{ Real unemployment } \\
\hline & & & & Number & $\begin{array}{r}\% \text { of } \\
\text { working } \\
\text { age } \\
\text { population }\end{array}$ \\
\hline Somerset & 5,980 & 5,700 & 4,800 & 16,500 & 5.1 \\
\hline Mendip & 1,350 & 1,400 & 700 & 3,400 & 5.0 \\
\hline Sedgemoor & 1,960 & 1,200 & 1,200 & 4,400 & 6.2 \\
\hline South Somerset & 1,040 & 1,800 & 1,400 & 4,200 & 4.4 \\
\hline Taunton Deane & 1,340 & 1,100 & 900 & 3,300 & 4.8 \\
\hline West Somerset & 300 & 300 & 600 & 1,200 & 6.4 \\
\hline WALES & 40,700 & 24,500 & 76,000 & 141,000 & 7.4 \\
\hline Isle of Anglesey & 1,040 & 500 & 1,200 & 2,700 & 6.8 \\
\hline Gwynedd & 1,320 & 1,300 & 1,300 & 3,900 & 5.2 \\
\hline Conwy & 1,420 & 600 & 2,800 & 4,800 & 7.3 \\
\hline Denbighshire & 1,060 & 500 & 2,600 & 4,200 & 7.6 \\
\hline Flintshire & 1,560 & 900 & 1,700 & 4,200 & 4.4 \\
\hline Wrexham & 1,440 & 1,100 & 2,300 & 4,800 & 5.7 \\
\hline Powys & 760 & 900 & 2,000 & 3,700 & 4.8 \\
\hline Ceredigion & 480 & 800 & 1,200 & 2,500 & 5.5 \\
\hline Pembrokeshire & 1,530 & 900 & 2,300 & 4,700 & 6.6 \\
\hline Carmarthenshire & 2,040 & 1,400 & 4,800 & 8,200 & 7.5 \\
\hline Swansea & 3,500 & 2,200 & 7,000 & 12,700 & 8.2 \\
\hline Neath Port Talbot & 2,080 & 1,100 & 6,200 & 9,400 & 10.7 \\
\hline Bridgend & 1,900 & 1,200 & 4,000 & 7,100 & 8.0 \\
\hline Vale of Glamorgan & 1,410 & 1,300 & 2,200 & 4,900 & 6.2 \\
\hline Cardiff & 5,460 & 3,200 & 6,800 & 15,500 & 6.3 \\
\hline Rhondda Cynon Taf & 3,490 & 2,300 & 8,800 & 14,600 & 9.8 \\
\hline Merthyr Tydfil & 1,080 & 500 & 2,500 & 4,100 & 11.0 \\
\hline Caerphilly & 3,050 & 1,400 & 5,700 & 10,100 & 9.0 \\
\hline Blaenau Gwent & 1,440 & 400 & 3,100 & 4,900 & 11.1 \\
\hline Torfaen & 1,270 & 500 & 3,100 & 4,900 & 8.6 \\
\hline Monmouthshire & 640 & 700 & 1,200 & 2,500 & 4.5 \\
\hline Newport & 2,790 & 800 & 3,500 & 7,100 & 7.7 \\
\hline SCOTLAND & 82,700 & 39,200 & 98,000 & 219,000 & 6.3 \\
\hline Aberdeen & 3,800 & 2,400 & 600 & 6,800 & 4.2 \\
\hline Aberdeenshire & 2,500 & 2,600 & 0 & 5,100 & 3.1 \\
\hline Angus & 1,510 & 700 & 1,600 & 3,800 & 5.4 \\
\hline Argyll \& Bute & 890 & 500 & 1,100 & 2,500 & 4.7 \\
\hline Clackmannanshire & 950 & 600 & 1,400 & 2,900 & 8.9 \\
\hline Dumfries \& Galloway & 1,530 & 1,100 & 2,700 & 5,300 & 5.9 \\
\hline Dundee & 3,290 & 500 & 4,500 & 8,300 & 8.4 \\
\hline East Ayrshire & 2,490 & 900 & 2,900 & 6,300 & 8.2 \\
\hline East Dunbartonshire & 1,040 & 700 & 900 & 2,600 & 3.9 \\
\hline East Lothian & 1,840 & 500 & 600 & 2,900 & 4.5 \\
\hline
\end{tabular}




\begin{tabular}{|c|c|c|c|c|c|}
\hline & \multirow[b]{2}{*}{$\begin{array}{r}\text { Claimant } \\
\text { Count }\end{array}$} & \multirow[b]{2}{*}{$\begin{array}{r}\text { Additional } \\
\text { ILO } \\
\text { unemployed }\end{array}$} & \multirow[b]{2}{*}{$\begin{array}{r}\text { Hidden } \\
\text { unemployment } \\
\text { on incapacity } \\
\text { benefits }\end{array}$} & \multicolumn{2}{|c|}{ Real unemployment } \\
\hline & & & & Number & $\begin{array}{r}\% \text { of } \\
\text { working } \\
\text { age } \\
\text { population }\end{array}$ \\
\hline East Renfrewshire & 670 & 800 & 600 & 2,100 & 3.6 \\
\hline Edinburgh & 5,410 & 4,700 & 4,300 & 14,400 & 4.1 \\
\hline Eilean Siar & 290 & 200 & 300 & 800 & 4.8 \\
\hline Falkirk & 2,350 & 1,500 & 2,700 & 6,500 & 6.4 \\
\hline Fife & 6,030 & 2,700 & 6,700 & 15,400 & 6.6 \\
\hline Glasgow & 14,320 & 3,000 & 23,400 & 40,700 & 9.4 \\
\hline Highland & 3,080 & 1,000 & 2,200 & 6,300 & 4.3 \\
\hline Inverclyde & 2,290 & -200 & 3,200 & 5,300 & 10.5 \\
\hline Midlothian & 1,010 & 700 & 1,200 & 2,900 & 5.3 \\
\hline Moray & 1,130 & 900 & 500 & 2,500 & 4.2 \\
\hline North Ayrshire & 3,260 & 1,500 & 3,900 & 8,700 & 10.4 \\
\hline North Lanarkshire & 6,100 & 2,100 & 9,000 & 17,200 & 7.8 \\
\hline Orkney Islands & 130 & 200 & 200 & 500 & 3.4 \\
\hline Perth \& Kinross & 1,130 & 1,400 & 1,600 & 4,100 & 4.4 \\
\hline Renfrewshire & 3,090 & 1,400 & 4,100 & 8,600 & 7.6 \\
\hline Scottish Borders & 1,180 & 1,000 & 1,300 & 3,500 & 5.2 \\
\hline Shetland Islands & 130 & 200 & 0 & 300 & 2.1 \\
\hline South Ayrshire & 1,660 & 600 & 2,400 & 4,700 & 6.9 \\
\hline South Lanarkshire & 4,410 & 2,300 & 6,800 & 13,500 & 6.7 \\
\hline Stirling & 950 & 900 & 700 & 2,500 & 4.2 \\
\hline West Dunbartonshire & 2,070 & 300 & 2,900 & 5,300 & 9.2 \\
\hline West Lothian & 2,200 & 1,700 & 3,600 & 7,500 & 6.5 \\
\hline
\end{tabular}

Sources: ONS, DWP and Sheffield Hallam estimates 



\section{CRESR \\ Sheffield Hallam University \\ City Campus \\ Sheffield S1 1WB \\ +44 (0)1142253073 \\ e: cresr@shu.ac.uk \\ w: shu.ac.uk/cresr}

ISBN: 978-184387-415-7

DOI: $10.7190 /$ cresr.2017.8224785923

\section{Sheffield Centre for \\ Hallam Regional Economic \\ University and Social Research}

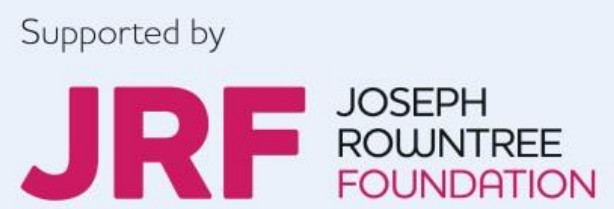




\section{Sheffield Hallam University}

The real level of unemployment 2017

BEATTY, Christina <http://orcid.org/0000-0003-0943-9979>, FOTHERGILL, Stephen <http://orcid.org/0000-0002-4201-0640> and GORE, Tony <http://orcid.org/0000-00020997-7198>

Available from the Sheffield Hallam University Research Archive (SHURA) at:

http://shura.shu.ac.uk/17175/

\section{Copyright and re-use policy}

Please visit http://shura.shu.ac.uk/17175/ and http://shura.shu.ac.uk/information.html for further details about copyright and re-use permissions. 